\title{
Expanding STEM Membership: Using Science Process Skills in a Social Justice Curriculum to Combat Stereotype Threats and Build Self-Efficacy in African American Students
}

Beverly A. King Miller, PhD

Georgia Southern University, Statesboro, Georgia, United States

Alma D. Stevenson, $\mathrm{PhD}$

Georgia Southern University, Statesboro, Georgia, United States

iD https://orcid.org/o000-0002-5844-7345

Shelli L. Casler-Failing, $\mathrm{PhD}$

Georgia Southern University, Statesboro, Georgia, United States

(iD) https://orcid.org/o000-0003-0042-8931

Contact: beverlyamiller3@gmail.com

almastevenson@georgiasouthern.edu

scaslerfailing@georgiasouthern.edu

\begin{abstract}
This qualitative study draws from an after-school service project conducted by three research professors located in the Southeastern United States. Students from a local Boys and Girls Club were given an opportunity to participate in an integrated literacy, science, and mathematics program. The program was geared towards African American students who are underrepresented in science, technology, engineering, and mathematics (STEM). Bandura's (1995) self-efficacy theory is used as a lens to analyze the effects of the social justice education strategies used in the program. The curriculum was anchored using science process skills that incorporate literature and portray scientists as role models who look like the students. This strategy was used to combat stereotype threats regarding African American intelligence and STEM ability that challenge STEM membership.
\end{abstract}

Keywords: science process skills, literacy, self-efficacy, stereotype threats, STEM

Date Submitted February 6, 2021 | Date Published: October 25, 2021

\section{Recommended Citation}

King Miller, B. A., Stevenson, A. D., \& Casler-Failing, S. L. (2021). Expanding STEM membership: Using science process skills in a social justice curriculum to combat stereotype threats and build self-efficacy in African American Students. Journal of Educational Research and Practice, 11(1), 259-278.

https://doi.org/10.5590/JERAP.2021.11.1.19

We wish to thank the director and staff of the Boys and Girls Club for allowing us to be a part of the educational process of the students who attend. We respect and honor you for daily service to the students and our community. 
King Miller et al., 2021

\section{Introduction}

By 2024, science, technology, engineering, and mathematics (STEM) jobs are expected to grow by $8.9 \%$ in the United States, whereas non-STEM jobs are expected to see a 6.4\% growth rate (Noonan, 2017). STEM workers from within the United States are needed to fill these jobs so reliance on foreign workers does not increase (Peri et al., 2014). Further, diversity is needed in the STEM workforce, so the industry adequately represents the demographics of the country and is inclusive of diverse voices (Noonan, 2017). Unfortunately, those of African descent continue to be underrepresented in STEM training that leads to STEM occupations (National Center for Science and Engineering Statistics [NCES], 2017). The persistence needed to major in a STEM field is rooted in student self-efficacy (Stearns et al., 2020).

African Americans often face challenges resulting from stereotype threats, such as intelligence threats (where threats to intelligence are used to explain the African American lack of inclusion in STEM training), which can affect self-efficacy and may result in STEM career barriers and STEM membership (Copur-Gencturk et al., 2020; Murray \& Herrnstein, 1994; Steele \& Aronson, 1995. Social beliefs regarding intelligence are often projected to students in their formative years from teachers who have lower expectations of students of color based upon social class and racial background (Baron et al., 1985; Lareau, 2011). This evidence suggests such beliefs can foster uncertainty and doubt, resulting in students questioning their own ability to pursue STEM training and careers. Students need opportunities to be successful in STEM content areas that would encourage belief in their ability and improve their self-efficacy; the authors posit that these opportunities can be presented in after-school programs.

This article presents data from an after-school Literacy in STEM program at the Boys and Girls Club of America (BGCA), where this service project was designed to combat the underrepresentation of African Americans in science, technology, engineering, and mathematics (STEM) by exposing them to a social justice curriculum, which incorporates literature portraying role models who look like them. This project was founded on a rich STEM and literacy curriculum anchored by science process skills (SPS) that concluded in a type of science fair presentation, where students were given an opportunity to do science and practice the scientific method in ways similar to STEM workers. Through the use of these science fairs, out-of-school programs can support STEM achievement among Black students (Young \& Young, 2018).

The curriculum design for this after-school STEM program was grounded on Bandura's $(1977 ; 1992 ; 1995)$ self-efficacy theory and followed social justice educational frameworks to provide students with an engaging, relevant curriculum where Black students who attended the program could make meaningful connections. The curriculum integrated literacy, science, and math in each unit, and it supported the Next Generation Science Standards (NGSS) goals for including writing, reading, and oral expression, as well as manipulating objects as a form of communication (McVee et al., 2017). Additionally, teaching SPS can serve as an anchor for science content since these are the tools of scientists (Coil et al., 2010); through SPS students can acquire the content knowledge needed for college and career success as a result of increased performance on assessment exams (Durmaz \& Mutlu, 2017).

Research has not fully addressed how using SPS in a social justice curriculum may contribute to increased self-efficacy in African American students to help combat stereotype threats that affect their STEM membership. Therefore, the question that guided this study was: How does scaffolding Science Process Skills in an after-school program build self-efficacy in African American students in order to combat stereotype threats? The research reported in this study is part of a larger investigation as to the effects of an extracurricular program focused on literacy, science, and mathematics integration to support students' interest in STEM disciplines. 
King Miller et al., 2021

\section{Theoretical Framework}

The research presented in this manuscript was analyzed through the lenses of self-efficacy theory (Bandura 1977; 1992; 1995) and social justice education that includes a culturally relevant curriculum (Ladson-Billings, 1995; Sleeter, 2005) and culturally responsive instructional strategies (Gay, 2018). The theory of self-efficacy is important to this research because African American students often must resist stereotype threats regarding STEM inclusion. Hegemonic structures that have sustained beliefs that African Americans are less intelligent and therefore do not possess the skills for STEM training continue to affect educational attainment (Rothstein, 2004). Determining ways to improve students' self-efficacy is instrumental to STEM membership. Additionally, integrating a social justice education pedagogical framework has been shown to improve the access and academic success of marginalized students of color (Carlisle et al., 2006; Gay, 2018; LadsonBillings, 1995; Newell et al., 2015; Sleeter, 2005).

\section{Self-Efficacy}

Albert Bandura's $(1977 ; 1992 ; 1995)$ theory of self-efficacy referred to the belief that a person holds regarding their capacity to perform the necessary activities in order to affect positive outcomes. Self-efficacy relies primarily on self-persuasion, which is determined by cognitive processes. Motivation is cognitively generated and is affected by one's belief about their ability to perform; the higher the belief that one is able to perform a task, the higher the motivation to perform the given task (Bandura, 1995). When students are motivated, or display self-efficacy, their willingness to participate and actively engage is visible. They speak, raise their hands, and demonstrate engagement through their participation. Bandura (1992) offered four sources of selfefficacy that foster motivation-mastery experiences, vicarious experiences, social persuasions, and physiological and emotional states.

Mastery experiences are those via which the individual's mastery of a task is relative to the amount of effort that went into obtaining the mastery. Through this, "success builds a robust belief in one's personal efficacy. Failures undermine it, especially if failures occur before a sense of efficacy is firmly established" (Bandura, 1995, p. 3).

Vicarious experiences are those where the individual draws motivation from seeing someone similar to themselves succeed in a task. Competent models help transmit the knowledge and teach observers the effective skills and strategies to help them navigate the environment (Bandura, 1995).

Social persuasions are verbally affirming support received from others. Although this is important, the most significant is one's ability to self-affirm. Self-affirmation is important because when there are no other social persuasions, the individual must be able to persuade themselves. If not, "people who have been persuaded that they lack capabilities tend to give up quickly in the face of difficulties" (Bandura, 1995, p. 4).

Physiological and emotional states are the final source of self-efficacy. That is, if someone holds negative beliefs about a task or experience, then their belief will lower their sense of self-efficacy. They will tend to resist the task or experience. Conversely, those with a positive mood or outlook in regard to the task or experience are more likely to hold positive beliefs that increase their sense of self-efficacy. Those beliefs will likely increase their motivation.

Bandura (1977) further stated that people tend to avoid activities that they believe exceed their ability. Rather, they pursue those that they judge themselves capable of managing. Oettingen (1995) added that people do not always have access to these four sources of efficacy. Hegemonic structures based on race may affect the efficacy sources that individuals may receive. For example, there may be limited vicarious experiences, social persuasions, or role models for socially and racially disadvantaged groups who have not been given equitable 
King Miller et al., 2021

access to education and economic opportunities. This is the reason why it was important to include images of STEM figures who were of African descent in the teaching of the science, literacy, and mathematics content.

\section{Social Justice Education}

Social Justice Education is based on various theoretical frameworks that advocate for an equitable curriculum to redress the structures of domination and subordination present across institutions of learning (Adams \& Love, 2009; Kavanagh \& Danielson, 2020). Social justice educators reject deficits that interpret "problems of people of color and/or from low-income communities mainly as personal failures;" instead, their problems are seen as consequences of unfairness in the political and educational system (Sleeter, 2005, p. 1). From this perspective, students are provided with a safe learning environment where they have equitable opportunities to learn.

Sleeter (2005) asserted that, historically, knowledge systems were subjugated due to the suppression of underrepresented people who were deemed "backward" or "uneducated" (p. 83). As a result, knowledge inclusion is determined by those who hold power, which means role models and heroes from some communalities may not be recognized. To redress this, she calls for a multicultural, inclusive curriculum for racially and ethnically diverse groups.

For this reason, the instructional approaches and resources utilized in this project were based on culturally relevant pedagogy aimed at empowering "students intellectually, socially, emotionally, and politically by using cultural referents to impart knowledge, skills and attitudes" (Ladson-Billings, 1995, p. 17-18). The instructional approaches were based on culturally responsive teaching principles where students' backgrounds were considered in the curriculum design (Gay, 2018; Ladson-Billings, 1995). This project implemented a curriculum that provided students with multiple opportunities to participate in challenging activities that enabled them to learn and develop a sense of ownership. The researchers used culturally relevant, enabling literature (Ladson-Billings, 1995; Tatum, 2006) that portrayed role models that students could identify with. When students see themselves in the curriculum-as characters in a book, as scientists performing experiments, or as actors in a video-there is increased interest in the curriculum and they are able to make stronger connections to the material being learned (Kinskey, 2020; Sleeter, 2005).

Social Justice Education "seeks to counter social inequities by creating an environment that challenges oppressive attitudes and behaviors, values multiple perspectives, and fosters community-building across social identity groups" (Carlisle et al., 2006, p. 57). Thus, discussions were encouraged that allowed for multiple perspectives that sought to acknowledge and value each student by promoting an environment of mutual respect. The researchers were able to cultivate reciprocal relationships with the students and to provide them with "meaningful opportunities for engagement" (Gorski, 2018, p. 149).

\section{Review of the Literature}

This review will consider the ways in which alternative after-school programs may benefit students. Further, it evaluates how SPS can be developed through such programs. The literature that was chosen to inform this study shares findings of how the programs and SPS impact student self-efficacy when incorporating social justice frameworks. This section begins with a review of literature on alternative education programs, transitions into SPS and equitable science education, and concludes with a brief statement on how the research being presented in this manuscript will add to existing research. 
King Miller et al., 2021

\section{Alternative Education Programs}

There is much learning that takes place outside of school walls. This can be structured or unstructured. Unstructured learning may take place in a kitchen as students help with a meal by reading or measuring the ingredients. More structured learning may include after-school programs that offer homework help or purposefully designed curriculum addressing numerous content areas such as STEM.

Research maintains that alternative educational programs support students socially, emotionally, and intellectually (National Research Council, 2015). There are many different types of after-school programs that offer various opportunities for tutoring and instruction. After School Matters, in Chicago, offers project-based learning designed to enhance students' soft skills, as well as produce a final product based on activities conducted with the students (Hirsch, 2011). This program is run by instructors with expertise in the discipline; soft skills learned include teamwork and communication in order for the project to be completed (Hirsch, 2011). Project-based clubs such as 4-H programs offer students an opportunity to plan an event or complete a project. Many are scientifically oriented, combining research and experimentation into the studies. These clubs are staffed primarily by volunteers (Hirsch, 2011). Another, possibly more familiar extracurricular program, is the Boys and Girls Club of America (BGCA). BGCA can be found in several cities across the United States and serve 4.73 million students annually (Boys and Girls Club of America, 2019).

The primary focus of the BGCA is on student development more so than academic development (Hirsch, 2011); building positive interactions between students and mentors in programs such as BGCA is shown to improve student achievement (Hirsch, 2011). The program offers students the opportunity to participate in activities such as sports, art, dance, and field trips. Another major focus of BGCA is providing a safe place for students who live in unsafe neighborhoods (Hirsch, 2011). However, the backbone of the club is the mentoring relationships provided by staff, and this is often provided through tutoring and homework help.

Springer and Diffily (2012) found that middle school students at a local BGCA, who participated in multiple BGCA programs, showed an increase in their school report card grade point averages and school attendance. Their findings were significant in that they measured the intensity (the total number of times a student attended a given BGCA program) and the breadth (the total number of different programs a student attended). They found that when students attend BGCA programs on a consistent basis there was a positive correlation in their academic performance (Springer \& Diffily, 2012).

Young and Young (2018) found that after-school programs, such as the BGCA, foster STEM achievement and interest in Black students that can influence classroom learning and affect academic outcomes. Newell et al. (2015) used the Simpson-Troost Attitude Questionnaire (STAQ-R) to determine if student attitudes regarding STEM improved in an after-school program. The post-tests revealed that students' attitudes regarding STEM training were more favorable and influenced student academic gains on a content knowledge assessment given. They reported an average gain of 6.6 points on the 25-item content knowledge assessment that was given to 134 students. Newell et al. (2015) explained that:

Many underrepresented minorities and low-income students do not pursue science courses in high school, and such programs may provide needed skills and motivation to keep students in the science “pipeline.” (p. 221).

The authors asserted that often students from underserved communities do not have the content knowledge needed for the STEM training pipeline, which can affect STEM access. For this reason, the research team intentionally developed the after-school curriculum to be highly engaging in order to develop student interest and content knowledge in STEM. 
King Miller et al., 2021

\section{Science Process Skills}

Science process skills (SPS) are the tools scientists use in science, but they are fundamental to critical thinking regardless of the discipline. SPS are often divided into basic and integrated skills. Basic skills include observing, communicating, classifying, measuring, inferring, and predicting (Rezba et al., 2007. Basic skills provide the foundation for the integrated SPS of identifying variables, constructing a table of data or graph, describing relationships between variables, acquiring and processing one's own data, analyzing investigations, constructing hypotheses, defining variables operationally, designing investigations, and experimenting (Rezba et al., 2007).

This integration of math and science creates authentic learning opportunities where math is embedded into real-world scenarios (Stephan et al., 2017). Coil et al. (2010) found that SPS are foundational in student understanding of science content and developing scientific literacy. They found that university faculty who teach undergraduate science courses reported that process skills benefit all students regardless of whether they pursue STEM training because it helps improve data analysis and critical thinking. Further, in a quantitative study of grade 7 science students, Durmaz and Mutlu (2017) reported that those students exposed to SPS, integrated in the instructional reading and experiments, showed an increase in post-performance content knowledge compared to their pre-performance results. Further, they noted that developed nations whose students are assessed on science exams, such as the Program for International Student Assessment (PISA), reported student success performance was greater when the curriculum emphasis included SPS.

The NGSS has integrated scientific and engineering design and practices as an acknowledgment of the research findings that support the integration of SPS. Each standard has three components: content, scientific and engineering practices, and cross-cutting concepts (National Science Teaching Association, n.d.). SPS elements, such as observation, experimenting, and communicating, are fundamental elements of NGSS.

\section{Equitable Science Education}

Stereotype threats based on intelligence impact STEM diversity. Steele \& Aronson (1995) described stereotype threats as a social-psychological predicament rooted in the belief system of American society. It is viewed as a threat to self-integrity that implies a person is inferior or incompetent in comparison to the dominant members of society (Martens et al., 2006). For students of African descent, these threats are often transmitted through media, environment, peers, and teachers (Quinn \& Spencer, 2001; Smith \& Hung, 2008). The lack of role models in STEM seems to confirm the effects of this threat and its assumptions. These practices create a climate of exclusivity for those of African descent where the communication is that they do not belong.

Ross and Stevenson (2017) reported that role models of all colors are beneficial to all children and backgrounds, so that all can gain an understanding and respect for other ethnic groups. Further, they found that although it was beneficial for underrepresented students to read about heroes that looked like them, this knowledge acquisition was valuable for all students regardless of race. Kinskey (2020) added that using images of prominent women in STEM helped to improve female student interests in STEM by allowing them to see STEM workers that looked like them. Her imaging included posting pictures of scientists from various racial and ethnic groups drawing from European, African American, Asian, and South American/Latina populations. She asserted that using images to connect lessons to real life through people and careers should be a daily occurrence in the science classroom (Kinskey, 2020).

Social justice STEM curricula are needed to counter the stereotype threats that are projected towards African American students. Stereotypes, such as "Blacks are lazy" and "girls do not do well in math and science," are often communicated loudly and effectively to students of African descent (Reyna, 2000). Further, when those of African descent show academic talent, they are often labeled as "freaks of nature" or "Black genius" in order to categorize this as atypical behavior (McGee, 2018). What often occurs is the internalization of these threats 
King Miller et al., 2021

to the point where the student believes the assertions and engages in negative self-talk (Manusov, 2011), saying things like, "I am not good at math."

To counter these stereotypes, building cultural competence through culturally relevant pedagogy is important so that African American students see scientists and inventors that look like them (Ladson-Billings, 2018). Using role models and examples that represent people of African descent counters the barrage of messages that can proliferate and be internalized that result in STEM exclusion. The Global Education Monitoring (GEM) Report acknowledges that global discrimination, stereotyping, and stigmatization have created barriers to inclusive education and access for those of African descent denying them an equitable quality education that promote lifelong learning opportunities (GEM Report, 2020).

The literature provides evidence that after-school programs, such as BGCA, can be beneficial to students of African descent in order to close the gap of educational exclusivity. Due to the far-reaching impact of BGCA, both in the number of students supported annually and the educational programs offered, creating programs focused on STEM activities can be instrumental in increasing interest among underrepresented student populations. Furthermore, activities that incorporate SPS and NGSS can support the learning occurring within the walls of students' schools. Additionally, research has not fully addressed how STEM and literacy instruction, founded on an equitable social justice pedagogical approach, can positively affect the self-efficacy of African American students in a BGCA program. The research reported in this manuscript is important because it recognizes the lack of diversity in STEM membership as a result of stereotype threats and attempts to redress this through academic support structures that use SPS to foster inclusivity. This research seeks to lend evidence that curricula using a social justice model can influence the self-efficacy of African American students in order to increase diversity in the STEM pipeline.

\section{Methods}

The focus of this study was to determine how SPS, when scaffolded within a social justice curriculum, can impact students' self-efficacy in an after-school program at the local BGCA in order to counter stereotype threats that limit the access of people of African descent to STEM training and careers. This qualitative study (Creswell, 2007) incorporated pedagogical frameworks that advocate for social justice education as a means to enhance student self-efficacy. The curriculum developed for this research was composed of activities that integrated science and mathematical concepts while supporting literacy skills development. The curriculum was strategically developed to include literature representing scientists and inventors from the racial/ethnic group of the participants who were African Americans from the rural Southeastern United States. All literacy, science, and mathematics content were aligned to the state standards.

This service project was conducted by three female professors from a large rural university in the southeastern part of the United States. The principal investigator was the literacy content specialist who recruited a science content specialist and a mathematics content specialist. Each had numerous years of experience working with the identified population.

The program was implemented over a 10-week period and included two 90-minute sessions per week. The student activities consisted of hands-on math and science activities and literacy activities that, when possible, intentionally included characters that were of African descent. The literacy strategies included: storytelling, reading picture storybooks and graphic novels, writing assignments, and discussions. Science activities included: testing for conductors and insulators, constructing electrical circuits, testing liquids to determine which liquid was water; making models to demonstrate the water cycle, and using K'Nex to build models. Mathematics activities included: graphing data, using Lego Robots to learn about proportions and apply Newton's Laws of Motion, and building models. 
King Miller et al., 2021

These activities served as a scaffold for the final product-a science fair project and presentation for the other student members and adults at the BGCA. These projects were designed and developed by the students and presented at a forum where over 100 of their peers from the BGCA cycled through to view and ask questions. It was the goal of the club director that this culminating presentation be used to inspire and motivate all students in STEM and encourage participation in their local school science competitions.

\section{Setting and Participants}

The research was conducted at the local BGCA located minutes from the university campus. This chapter of BGCA serves nearly 400 children annually and works closely with the area elementary and middle schools where the students attend. This chapter of BGCA is located within a small city that is surrounded by rural communities-the largest urban area is about a one-hour drive away.

The students who participated were in grades 6-7 from two of the three local middle schools. At the beginning of the program, there were 11 African American participants, but due to transportation issues many students left early and were not able to stay for the entire 90-minute program sessions on the designated days. There were six participants that completed the entire 10-week program-four male and two female students. The participants were selected by the BGCA director and students, and parents/guardians provided assent and consent. Pseudonyms were used to protect the identity of the participants and they will be referred to using their gender and an assigned number (i.e., Male Student 1, Female Student 3).

\section{Program Overview}

As a research team, we reviewed the state standards for our target population, which was middle school students. We examined the science, mathematics, and literacy standards and decided on the science content standards in order to weave the math and literacy around the specific topics. The science content focus selected was physical science and instructional topics selected were renewable/nonrenewable resources, water and the water cycle, Newton's Laws, and natural disasters.

Each topic was introduced by the literacy researcher, through a focused book reading, in order to create a foundation built on literacy. She used a combination of nonfiction and fiction reading texts inclusive of graphic novels. The math researcher supported the content focus through the inclusion of numeracy and data collection and analysis into the various experimental lab activities. These reflected middle school mathematics standards for statistics and probability that required students to use data to draw inferences for analysis (CCSSI, 2020). To undergird the science content, the science researcher incorporated Science Process Skills (SPS) as a thread to build science content and develop student skills.

We began the program on the first day with literacy through the reading of the book The Boy Who Harnessed the Wind by Kamkwamba and Mealer (2012) to engage the students, make a meaningful connection, and as a springboard to introduce the first topic in the program. Each subsequent science topic was introduced by the literacy researcher with a culturally and content-relevant text in a graphic novel format. The science researcher's responsibility was to connect the literacy content to the science component. The readings were referred to throughout many of the science lessons. The math researcher's responsibility was to connect the literacy and science components to real-world applications of mathematics through data collection and modeling processes.

During the initial unit on renewable/non-renewable resources, the students were reminded of the character William from the book The Boy Who Harnessed the Wind by Kamkwamba and Mealer (2012) and his need to solve the water problem in his village in Malawi that resulted in an apparatus to generate electricity. The book was used as a foundation for the first activity on electricity and was often referred to throughout the program. Additionally, a second literacy component was added, which included the stories of two African American scientists Louis Latimer and Granville T. Woods. 
This study incorporated SPS such as: observations, estimating, and measuring and collecting data to name a few, while also integrating numeracy into the science activities. Science process skills (SPS) were implemented through students clustered in whole groups, team activities in small groups, and then individual instructional activities. It appeared most students were uncomfortable with answering questions and speaking orally, so we began the first science activity as a whole group project. We felt that providing the students the opportunity to work collaboratively, as one team, would allow them to develop confidence in their own abilities as well as trust for each other and us.

\section{Science Process Skills}

SPS were integrated throughout each activity in the program and included: (1) predicting, (2) observing, (3) hypothesizing, (4) investigating, (5) measuring, (6) data collection, (7) making models, and (8) communicating. Table 1 below shows how the SPS aligned with each topic. The topics were scaffolded so that activities build on simple process skills (i.e., predicting, observing) to ones that were more complex (i.e., investigating, communicating). All components needed for the product, the science fair project, and the presentation were scaffolded through SPS.

Table 1. Science Process Skills Addressed by Topic

\begin{tabular}{|c|c|c|c|}
\hline Science Topic & Science Process Skill & $\begin{array}{l}\text { \# Process Skills } \\
\text { for Activity }\end{array}$ & Activity Type \\
\hline \multicolumn{4}{|l|}{ Renewable/ } \\
\hline \multicolumn{4}{|l|}{ Nonrenewable Resources } \\
\hline $\begin{array}{l}\text { Test for Conductors and } \\
\text { Insulators }\end{array}$ & $\begin{array}{l}\text { predicting, observing, data } \\
\text { collection, investigating }\end{array}$ & 4 & whole group \\
\hline $\begin{array}{l}\text { Make a Circuit Using Christmas } \\
\text { Lights-Recycled Materials }\end{array}$ & $\begin{array}{l}\text { observing, making a model, } \\
\text { investigating }\end{array}$ & 3 & $\begin{array}{l}\text { group/individual } \\
\text { /help from } \\
\text { instructors }\end{array}$ \\
\hline \multicolumn{4}{|l|}{ Water and the Water Cycle } \\
\hline Water Cycle Intro and Song & communication & 1 & whole group \\
\hline $\begin{array}{l}\text { Water Activity: Observe } \\
\text { Evaporation in Plastic Bag }\end{array}$ & $\begin{array}{l}\text { investigating, observing, } \\
\text { hypothesizing, communicating }\end{array}$ & 4 & individual \\
\hline Water Cycle Wheel & making models & 1 & individual \\
\hline $\begin{array}{l}\text { Experiment: Which Liquid is } \\
\text { Water? (Intro to Scientific } \\
\text { Method) }\end{array}$ & $\begin{array}{l}\text { collecting data, investigating, } \\
\text { observing, hypothesizing, }\end{array}$ & 4 & group: teams \\
\hline $\begin{array}{l}\text { Building Well With K'Nex: NGSS } \\
\text { Engineering goal } \\
\text { Newton's Laws }\end{array}$ & making a model, communicating & 2 & group: teams \\
\hline Robotics Activity & $\begin{array}{l}\text { collecting data, measuring, } \\
\text { investigating, observing, predicting }\end{array}$ & 5 & group: teams \\
\hline \multicolumn{4}{|l|}{ Natural Disasters } \\
\hline $\begin{array}{l}\text { Water Splatter Drop Height: } \\
\text { Introduce Graphing }\end{array}$ & $\begin{array}{l}\text { predicting, hypothesizing, observing, } \\
\text { measuring, collecting data (graphing), } \\
\text { investigating, communicating }\end{array}$ & 7 & Group: teams \\
\hline \multicolumn{4}{|l|}{$\begin{array}{l}\text { Final Activity: Science Fair } \\
\text { Project }\end{array}$} \\
\hline $\begin{array}{l}\text { Student Choice for Research } \\
\text { Experiment }\end{array}$ & $\begin{array}{l}\text { predicting, hypothesizing, observing, } \\
\text { measuring, collecting data, } \\
\text { investigating, making a model } \\
\text { (graph), communicating }\end{array}$ & 8 & $\begin{array}{l}\text { students } \\
\text { determined } \\
\text { partners and } \\
\text { project }\end{array}$ \\
\hline
\end{tabular}


King Miller et al., 2021

\section{Data Collection and Analysis}

Data were collected throughout the program from several different sources; collecting data from multiple sources allows for triangulation of the findings in order to deem the findings both reliable and valid (Patton, 2002; Yin, 2009). The data that was collected consisted of student notebooks that included science data collection worksheets and drawings, science surveys, reflection responses, video presentations from the culminating science fair event, and researcher field notes. For this manuscript focusing on SPS, data were triangulated using student journals which included their writings, drawings, and science data collection worksheets; video presentation from the science fair; and the use of researcher field notes (Marshall \& Rossman, 2006).

Data were analyzed, classified, and coded recursively using a naturalistic, interpretive approach (Denzin \& Lincoln, 2005). Correlations across the data were highlighted and analyzed to support the explanations of emergent themes. Observational notes, researchers' journals, and discussions between the researchers about the data were used to triangulate findings (Baxter \& Jack, 2008) and to find regularities in recurring patterns (McMillan \& Schumacher, 2010).

\section{Findings}

\section{Effects of Scaffolding Science Process Skills}

Throughout the 10 weeks, each unit added SPS where students worked on individual or group projects (as shown in Table 1). The initial electricity lesson was the first to integrate SPS. After testing for conductors and insulators and practicing how to make simple circuits, the students were challenged to synthesize this knowledge by constructing a circuit board with a switch. Students were helped, as needed, and allowed the choice to work alone or form their own buddy groups. Students were scaffolded by questioning throughout the activity so no one felt singled out, and they were given praise and encouragement when we saw a step that would lead to success-the light being turned on by the switch.

As the students achieved success, they were excited to share with their peers how they completed the switch. This was particularly telling from Male Student 1, who had academic deficits in reading and writing. As a grade 6 student, he had strong oral and verbal skills; however, he lacked basic literacy and mathematical skills. The researchers had to remind students to be respectful of him during reading, however, because for this activity he had strong spatial intelligence and was able to problem solve to successfully complete the task. He was the first to successfully have a working circuit and paper clip switch that turned the light on and off. As he shared his knowledge with the others, an increase in self-efficacy is evidenced through the confidence he showed as he demonstrated to his peers how he got his switch to work with the circuit.

At the conclusion of each segment, the literacy researcher provided writing prompts and questions. Figure 1 represents a student's response. One question asked them to: Talk about your experiment with the batteries and the light bulbs. What did you learn about electricity and circuits? 
King Miller et al., 2021

Figure 1. Male Student \#1 Response to Questions in Regard to Electricity Activity

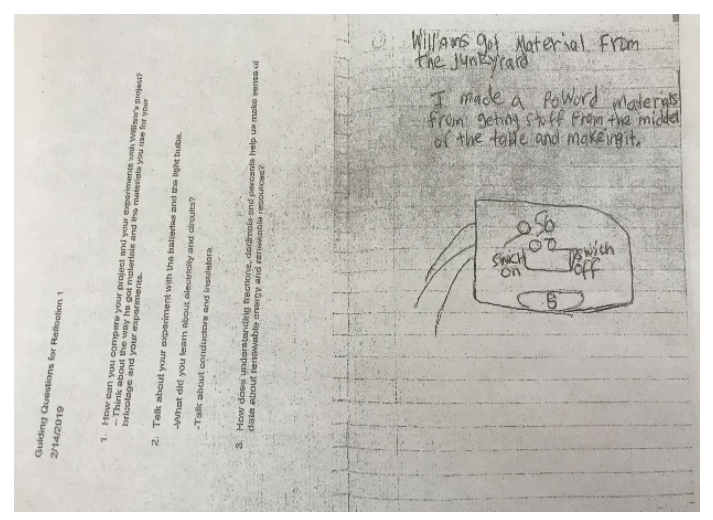

In Figure 1, the student struggles with writing, but his drawing is evidence that he understood the science concept of circuits. In his drawings, he uses the symbols learned for battery, the lines for the wire, and the symbol for the lightbulb. He also clearly marks the "on" and "off" switch made from a paper clip that demonstrates the ability to turn the light on and off. NGSS calls for students to use models to represent their thinking (Why K-12 Standards Matter, 2020). This example from Male Student 1 demonstrates that, although he could not adequately narrate his ideas, his drawings show conceptual mastery.

During the water cycle lesson, students listened to a video on the water cycle, sang a water cycle song, and made a paper model of the water cycle. Then they made a model using blue-colored water in a plastic sandwich bag that was placed in the window in order to observe the process of evaporation and condensation. In this lesson, the SPS included: investigating, observing, making models, and communicating. The communication component was a new skill and was implemented by using a R.A.F.T. (Role, Audience, Format, Topic) activity that required the students to write a story pretending they were a drop of water traveling through the water cycle; they were expected to use the vocabulary words learned from the water cycle and share their writing with the group.

This writing activity allowed the students to share their creative side while providing evidence of their scientific understanding in a manner that supported literacy development. Below are examples of two student narratives that show their diverse abilities. In the examples, the vocabulary words are underlined for emphasis.

If I was a raindrop [sic] and start floating that is evaporation. Once you get in the cloud that is called condensation. When you start to pour down that is precipitation (Male Student 2).

I am a drop of water. I started in the Atlantic Ocean, but I evaporated while I was drowning. I turned into gas and started floating in the air and I was fused with other drops of water that turned into gas and formed a cloud. Soon the cloud we made got dark and we started to fall which is called precipitation as rain. After I fell from the cloud I landed on land and this is called collection and the cycle repeats. (Male Student 6)

The story told by Male Student 2 is a retelling of the water cycle and does not include many story elements, whereas Male Student 6 offered a more descriptive story. His story offers details and a level of creativity. He takes the time to place his water droplet geographically close to home and weaves a tale that includes three vocabulary words from the water cycle lesson. Although the students reported to not always enjoy the reading or the writing components, their verbal expressions and SPS were enhanced through the literacy practice. Further, their beliefs in their content knowledge acquisition led to improved self-efficacy, which in turn left them feeling more comfortable when sharing their ideas. 
SPSs were scaffolded throughout the weekly activities, but the scientific method was introduced weeks later with the water splatter activity. The final project required students to design a question that could be answered through a science investigation, similar to a science fair. Male Students 1 and 2 decided they would explore the electricity unit again and design a larger circuit board to consider the brightness of bulbs when adding a larger power source; they wanted to design a product that included series and parallel circuits. Male Students 3 and 6 decided to investigate the effects of evaporation of liquids based upon heat intensity produced from light. Finally, Female Student 4 began a project with Female Student 5 , however, ended up completing the project independently due to a schedule change in Female Student 5's pick-up time. The investigation attempted to determine temperature increase for a controlled amount of water during a set time period.

\section{Planning and Creating the Science Project}

The science content researcher brought over 25 years of science fair knowledge and used a social justice approach in the preparation of students for the project. She believed students should be taught how to set up a project board that is well constructed and uses measurement to visually structure the presentation board. First, students were shown how to choose complementary colors of colored paper that would best represent their project. For example, Male Student 3 decided to use red and yellow construction to represent the experiment on light and heat. The researchers brought a paper cutting board and taught students how to accurately measure and lay out the components for their board. Also, students learned how to use rubber cement to affix their papers so that it was free of the smudges that regular glue can often leave.

At the start of the project there was some resistance because the few students who had participated in a school science fair previously were not accustomed to this level of attention to detail in the project construction. From the science researcher's past experience, presentation boards and oral practice are often omitted from the science fair process, so it was important to include these components in our program. In the end, when the students stood and looked at their end product they smiled and were pleased with what they produced. After the boards were completed (see Figures 2 and 3), the students began to prepare for the presentation. They were asked questions and reminded that scientists must also learn how to communicate their findings. Again, communication as an SPS was fundamental.

Figure 2. Female Student 4’s Presentation Board

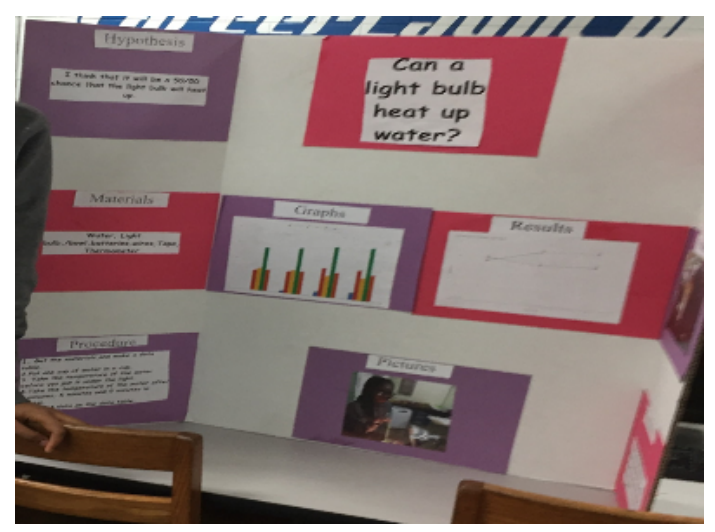


King Miller et al., 2021

Figure 3. Male Student 1's Circuit Board

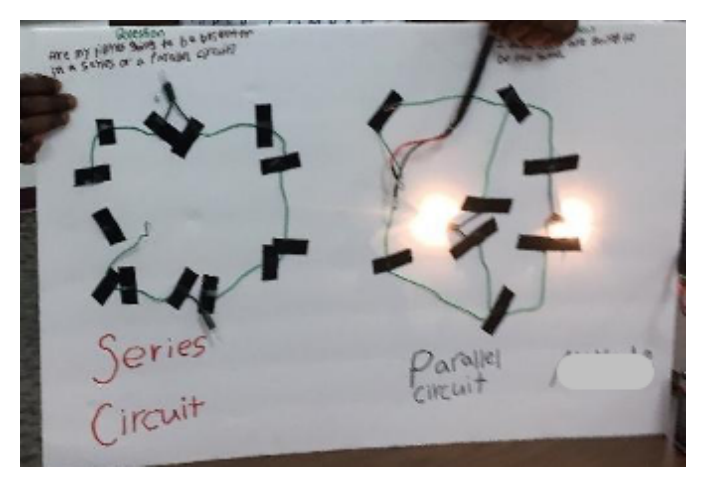

\section{Discussion}

The research question that guided this study focused on the effects that SPS, in a social justice curriculum, have on the self-efficacy of African American students who are often excluded from STEM due to stereotype threats. Data sources included: student journals that incorporated their writings and drawings, researcher field notes and video coverage from the mock science fair presentation.

The researchers each kept fieldnotes and held brief weekly discussions. Discussions centered around the lesson content and implementation, as well as observations of student engagement and confidence (which are evidence of increased self-efficacy). The student reflections and writing submissions also offered additional evidence that self-efficacy was improving as time in the program progressed.

The video and pictures from the science fair presentations offered summative support on the effects of selfefficacy as a result of SPS being scaffolded to culminate in a project. Using Bandura's (1995) theory of selfefficacy as a gauge, evidence emerged that supported student increase in self-efficacy resulting from their confidence in scientific content knowledge acquisition. This was revealed through three components. First, there was evidence of increase in their communication. Whether verbal or written, students demonstrated a positive change in their self-efficacy by their increased participation in the activities. Second, there was a connection to literacy that incorporated role models that looked like the students, which the students often referred to in their writing and discussion. Finally, there was willingness on the part of the students to participate in the science fair presentation.

\section{Self-Efficacy Through Increase in Communication}

Self-efficacy is the belief that one is capable of completing a task successfully; as self-efficacy increased so did the students' motivation for learning (Bandura, 1995). African American students often struggle with selfefficacy due to socio-cultural system beliefs and hegemonic structures that have limited access to educational attainment (Rothstein, 2004). These systemic beliefs include stereotype threats regarding intelligence that attempt to define those of African descent as being less capable in their ability to master subjects such as math and science (Martes et al., 2006; Reyna, 2000; Smith et al., 2008).

Midgley et al. (1996) found that there is a correlation between self-efficacy and self-handicapping or avoidant behaviors. Self-handicapping behaviors included withdrawal and procrastination to cover fears of failure or ability to perform (Midgley et al., 1996; Tyler et al., 2016). By using praise when they reached a milestone and encouraging them to keep trying, we bolstered their self-efficacy and reinforced their feelings of competence, which reduced their need to use self-handicapping strategies. This could explain why the students initially did 
not want to participate and would not answer questions. Tyler et al. (2016) noted that in academic settings Black male students used self-handicapping behaviors in order to cover their fears regarding their potential performance.

As students in the BGCA program became more confident in their abilities, so did their willingness to share their ideas, sing songs, work with each other and value each other's perspectives (Kinskey, 2020). Using praise and encouragement helps to combat self-handicapping behaviors that result from internalized negative self-talk. Sosa and Gomez (2012) reported that when teachers used encouragement, praise, and compliments, it countered the threats for Latina elementary students who reported that they could not succeed in science; a second strategy was acknowledging student effort. Helping to bolster self-efficacy throughout the lessons where SPS was incorporated enabled the students to persist and complete the science fair project and presentation.

\section{Self-Efficacy Through Literacy Connection}

At the exit interview, many students shared that reading was their least favorite activity in the program. This reflects a disconnect in their understanding of the value of the reading component. They did not fully understand the anchor that the stories and graphic novels provided that enabled their comprehension of the science content. They did not realize that using the read-aloud supported their language and thinking skills development (Lennox, 2013). Delpit (2006) challenges educators to be careful not to deny the interpretations of students from their writing, but rather work to understand their rationale. One of the writing prompts given asked students to reflect upon the first book, The Boy Who Harnessed the Wind (Kamkwamba et al., 2009). Male Student 3 wrote:

What motivated William is that his family was poor and they didn't have money so he went out and found a book and made something that changed his life.... I like how he was so hard working and creative because he kept going and never gave up even though everyone doubted him (journal entry).

From this writing we can glean that the student remembered details from the story, but also pondered the importance of hard work as a theme that he recognized in the story. As a result, although students may not have found enjoyment in this part of the program, they show an increase in language acquisition and reflective thinking skills.

Using social justice education practices, Delpit (2006) encouraged teachers to appreciate linguistic diversity and not see any form of expression as "wrong." Therefore, we did not correct academic language but merely asked for clarity to understand their meaning. There are narratives where spelling errors can be found; we did not seek to correct grammar but encouraged them to share their ideas.

Writing and being able to orally present is a sign of power and privilege (Colyar, 2013). To be culturally responsive, we were careful not to critique words and structure but rather to support and listen to voice. Newkirk and Kittle (2013) shared that when students are given time to write, their fluency and proficiency as writers increase. Including writing as part of science helped students to cement the learning through narratives and pictures.

Even though students were given a handout about Latimer and Granville T. Woods, we chose to tell their stories orally during the instruction. After constructing a simple circuit with a Christmas light, the science researcher shared that although Thomas Edison is credited with the invention of the light bulb, it was Latimer, his apprentice, who developed a more efficient filament so that the bulbs would not get too hot and explode. In exposing the students to scientists credited with vital contributions that looked like them, it fostered a connection that served to build self-efficacy. As evidence, one student wrote at the end of the day for their reflection: 
I learned about some of black history. My experiences here so far was [sic] good and I hope we will continue to keep doing stuff that we are doing (Male Student 3, journal entry).

His narrative reflects a positive application to the inclusion of African American scientists who he racially identified with. Through this strategy, we hoped to change the narrative of STEM to a more inclusive one by showing current and historical STEM role models that looked like our students, thus building their cultural competence (Ladson-Billings, 2018).

\section{Self-Efficacy Through Willing Participation in Science Fair}

It has been the science content researcher's experience as a former middle and high school science teacher and professional development provider for teachers on the science fair, that teachers often do not enjoy the science fair project because of the amount of time and effort needed to support students through the process; it is not conducive in a school climate driven by high stakes testing. Crist (2019) found that when students are given an opportunity to identify a problem, research and plan their independent experiment, and design a means to share their findings, they tend to be more engaged in the process. By having the students practice in an after-school setting it builds their SPS in investigating and communicating. These skills are important to all academic disciplines. Students need to be given time to work and use their own imaginations to structure their investigations (Miles, 2012). In a normal school climate this is not always possible.

Few other school projects produce scientific inquiry and the nature of science as learned through the science fair project (McComas, 2011; Schmidt \& Kelter, 2017). Using this venue to expose students to the work of scientists allows them to see themselves in the STEM pipeline. Tai et al. (2006) found that 8th grade students who participated in an after-school STEM program and who were interested in science careers, were more likely to pursue a 4-year degree in science.

Four of the six students from the program participated for the final mock science fair at their BGCA. Two of them had partners who initially worked with them but chose not to complete the process. Although the numbers are small, it reflects that for this 10 -week program, $66 \%$ of our students persisted in the program and completed the science fair project and presentation. Not many other projects stretch students in so many content areas as the science fair. The integration of math, science, and literacy are foundational to the success of students who are interested in persisting in STEM training in order to participate in a STEM career.

\section{Conclusion}

This service project proposed to address the self-efficacy of African American students in STEM by exposing them to a social justice curriculum. Included in the curriculum was a rich STEM and literacy curriculum anchored by SPS that concluded with a science fair type presentation by the students. Stereotype threats limit access to STEM for those of African descent. Building self-efficacy through a social justice curriculum is important to combat the effects of these threats.

This research demonstrated that scaffolding SPS through a social justice education framework can positively affect the self-efficacy of students. The findings revealed that students in the study demonstrated an increased confidence in content knowledge through the models they built, their written reflections, narratives, and final science fair project presentation. There was evidence that self-efficacy increased because they successfully presented their science fair projects to almost 100 of their peers at the BGCA they attended.

Many students struggle with self-efficacy when it comes to STEM content. However, for African Americans, the issue is intensified due to stereotype threats regarding intelligence and ability that serve to deny STEM 
access. Through this program, we were able to teach SPS and allow students to design and test their own project ideas that led to their science fair presentation.

Although the findings are promising, there are limitations present within this research. First, measures were taken during the data analysis to ensure validity and reliability, but the small sample size that resulted from the few students who completed the entire 10 weeks does affect the findings. To address this issue for the future, communication as to the requirements and time commitment for the program will need to be part of the participant selection criteria. Secondly, this program has only been conducted in one community for one 10-week period; additional studies should be replicated within this community and with communities of similar student populations as a means to support the findings herein.

Scaffolding SPS increases STEM content knowledge. Through alternative programs such as BGCA, students can benefit from STEM programs that incorporate a social justice education framework. When social justice educational frameworks that allow students to see themselves represented in STEM are adopted, we will finally see the gap in underrepresented groups begin to narrow. 
King Miller et al., 2021

\section{References}

Adams, M., \& Love, B. (2009). A social justice education faculty development framework for a post-Grutter era. In K. Skubikowski, C. Wright, \& R. Graf (Eds.), Social justice education: Inviting faculty to transform their institutions (1st ed., pp. 3-19). Stylus Publishing.

Bandura, A. (1977). Self-efficacy: Toward a unifying theory of behavioral change. Psychological Review, 84(2), 191-215. https://doi.org/10.1037/0033-295X.84.2.191

Bandura, A (1992). Exercise of personal agency through the self-efficacy mechanism. Psychological Society, 48(187), 397-427.

Bandura, A. (Ed.). (1995). Self-efficacy in changing societies. Cambridge University Press.

Baron, R., Tom, D., \& Cooper, H. (1985). Social class, race, and teacher expectations. In J. Dusek (Ed.), Teacher expectancies (pp. 251-270). Lawrence Erlbaum Associates.

Baxter, P., \& Jack, S. (2008). Qualitative case study methodology: Study design and implementation for novice researchers. Qualitative Report, 13(4), 544-559. https://doi.org/10.46743/2160$3715 / 2008.1573$

Boys and Girls Club of America. (2019). Annual Report. https://www.bgca.org/about-us/annual-report

Coil, D., Wenderoth, M. P., Cunningham, M., \& Dirks, C. (2010). Teaching the process of science: Faculty perceptions and an effective methodology. Life Science Education, 9(4), 524-535. https//doi.org/10.1187/cbe.10-01-0005

Colyar, J. E. (2013). Reflections on writing and autoethnography. In S. H. Jones, T. E. Adams, \& C. Ellis (Eds.). Handbook of Autoethnography (pp. 363-383). Left Coast Press.

Common Core State Standards Initiative. (2020, December 31). Grade 7: Statistics and probability. http://www.corestandards.org/Math/Content/7/SP/

Copur-Gencturk, Y., Cimpian, J. R., Lubienski, S. T., \& Thaker, I. (2020). Teachers' bias against the mathematical ability of female, Black, and Hispanic students. Educational Researcher, 49(1), 30-43. https://doi.org/10.3102/0013189X19890577

Creswell, J. W. (2007). Qualitative inquiry and research design: Choosing among five approaches (2nd ed.). SAGE Publications.

Crist, C. (2019, September). Schools reenergize next-generation science fairs. District Administration, 57(8), https://districtadministration.com/schools-energize-next-generation-science-fairs/

Delpit, L. (2006). Other people's children: Cultural conflict in the classroom. The New Press.

Denzin, N. K., \& Lincoln, Y. S. (Eds.). (2005). The SAGE handbook of qualitative research (3rd ed.). SAGE Publications.

Durmaz, H., \& Mutlu, S. (2017). The effect of an instructional intervention on elementary students' science process skills. The Journal of Educational Research, 110(4), 433-445. https://doi.org/10.1080/00220671.2015.1118003

Global Education Monitoring Report. (2020). Global Education Monitoring Report 2020: Inclusion and education: All means all (3rd ed.). UNESCO. https://en.unesco.org/gemreport/report/2020/inclusion

Gorski, P. C. (2018). Reaching and teaching students in poverty: Strategies for erasing the opportunity gap (2nd ed.). Teachers College Press. 
King Miller et al., 2021

Hirsch, B. (2011). Learning and development in after-school programs. Phi Delta Kappan, 92(5), 66-69. https://doi.org/10.1177\%2Fo03172171109200516

Kamkwamba,W., Mealer, B., \& Zunon, E. (2012). The boy who harnessed the wind. Harper-Perennial.

Kavanagh, S. S., \& Danielson, K. A. (2020). Practicing justice, justifying practice: Toward critical practice teacher education. American Educational Research Journal, 57(1), 69-105. https://doi.org/10.3102/0002831219848691

Kinskey, M. (2020, May). Girls in STEM. Using images to improve female students' interest and motivation in science, technology, engineering and mathematics. Science and Children, 57(7), 56-59.

Ladson-Billings, G. (1995). Toward a theory of culturally relevant pedagogy. American Educational Research Journal, 32(3), 465-491. https://doi.org/10.3102/00028312032003465

Ladson-Billings, G. ( 2018). I used to love science ... and then I went to school: The challenge of school science in urban schools. In J. Settlage, S. A. Southerland, L. K. Smetana, \& P. S. Lottero-Perdue (Eds.), Teaching science to every child: Using culture as a starting point (3rd ed, pp. xi-xvii). Routledge Press.

Lareau, A. (2011). Unequal childhoods: Class, race, and family (2nd ed.). University of California Press.

Lennox, S. (2013). Interactive read-alouds-an avenue for enhancing children's language for thinking and understanding: A review of recent research. Early Childhood Education Journal, 41(5), 381-389. https://doi.org/10.1007/s10643-013-0578-5

Manusov, V. (2011). Being civil with ourselves. Spectra, 47(3), 16-19.

Marshall, C., \& Rossman, G. B. (2006). Designing qualitative research (4th ed.). SAGE Publications.

Martens, A., Johns, M., Greenberg, J., \& Schimel, J. (2006). Combating stereotype threat: The effects of selfaffirmation on women's intellectual performance. Journal of Experimental Social Psychology, 42(2), 236-243. https://doi.org/10.1016/j.jesp.2005.04.010

McComas, W. F. (2011, November). The science fair: A new look at an old tradition observations, reflections, and recommendations from our guest editor. The Science Teacher, 78(8), 34-38.

McGee, E. (2018). Black genius, Asian fail: The detriment of stereotype lift and stereotype threat in highachieving Asian and Black STEM students. AERA Open, 4(4), 1-16. https://doi.org/10.1177/2332858418816658

McMillan, J. H., \& Schumacher, S. (2010). Research in education: Evidence-Based inquiry (7th ed.). Pearson.

McVee, M., Silvestri, K., \& Shanahan, L. English, K. (2017) Productive communication in an afterschool engineering club with girls who are English language learners. Theory Into Practice, 56(4), 246-254. https://doi.org/10.1080/00405841.2017.1350490

Miles, R. (2012). Increasing student participation in science fair competitions. Science Scope, 36(1), 66-70.

National Research Council. (2015). Identifying and supporting productive STEM programs in out-of-school settings. Committee on Successful Out-of-School STEM Learning. Board on Science Education, Division of Behavioral and Social Sciences and Education. The National Academies Press.

National Science Teaching Association. (n.d.). Why $K-12$ science standards matter-and why the time is right to develop next generation science standards. https://ngss.nsta.org/why-standardsmatter.aspx

Newell, A. D., Zientek, L. R., Tharp, B. Z., Vogt, G. L., \& Moreno, N. P. (2015). Students' attitudes toward science as predictors of gains on student content knowledge: Benefits of an after-school program. School Science and Mathematics, 115(5), 216-225. https://doi.org/10.1111/ssm.12125 
King Miller et al., 2021

Newkirk, T., \& Kittle, P. (Eds). (2013). Children want to write: Donald Graves and the revolution in children's writing. Heinemann.

Noonan, R. (2017). STEM jobs: 2017 update (ESA Issue Brief \#02-17). U.S. Department of Commerce. https://files.eric.ed.gov/fulltext/ED594354.pdf

Oettingen, G. (1995). Cross-cultural perspectives on self-efficacy. In A. Bandura (Ed.), Self-efficacy in changing societies (pp. 149-176). Cambridge University Press.

Patton, M. Q. (2002). Qualitative research and evaluation methods. SAGE Publications.

Peri, G., Shih, K., \& Sparber, C. (2014). Foreign STEM worker and native wages and employment in US cities (Working paper 20093). National Bureau of Economic Research. https://www.nber.org/system/files/working_papers/w20093/w20093.pdf

Quinn, D. M., \& Spencer, S. J. (2001). The interference of stereotype threat with women's generation of mathematical problem-solving strategies. Journal of Social Issues, 57(1), 55-71. https://doi.org/10.1111/0022-4537.00201

Reyna, C. (2000). Lazy, dumb, or industrious: When stereotypes convey attribution information in the classroom. Educational Psychology Review, 12(1), 85-110. https://doi.org/10.1023/A:1009037101170

Rezba, R., McDonnaugh, J., Matkins, J., \& Sprague, C. (2007). Learning and assessing science process skills (5th ed.). Kendall/Hunt Publishing.

Ross, S., \& Stevenson, A. (2017). When walking the walk changes the talk: Using critical reflection to inform practices of social justice research and social justice education. In D. D. Liston \& R. Rahimi (Eds). Promoting social justice through the scholarship of teaching and learning (pp. 189-208). Indiana University Press.

Rothstein, R. (2004). Class and schools: Using social, economic, and educational reform to close the BlackWhite achievement gap. Teachers College Press.

Schmidt, K. M., \& Kelter, P. (2017). Science fairs: A qualitative study of their impact on student science inquiry learning and attitudes toward STEM. Science Educator, 25(2), 126-132.

Sleeter, C.E. (2005). Un-standardizing curriculum: Multicultural teaching in the standards-based classroom. Teachers College Press.

Smith, C. S., \& Hung, L.-C. (2008). Stereotype threat: Effects on education. Social Psychology of Education, 11(3) 243-257. https://doi.org/10.1007/s11218-008-9053-3

Sosa, T., \& Gomez, K. (2012). Connecting teacher efficacy beliefs in promoting resilience to support of Latino students. Urban Education, 47(5), 876-909. https://doi.org/10.1177/0042085912446033

Springer, K., \& Diffily, D. (2012). The relationship between intensity and breadth of after-school program participation and academic achievement: Evidence from a short-term longitudinal study. Journal of Community Psychology, 40(7), 785-798. https://doi.org/10.1002/jcop.21478

Stearns, E., Bottia, M. C., Giersch, J., Mickelson, R. A., Moller, S., Jha, N., \& Dancy, M. (2020). Do relative advantages in STEM grades explain the gender gap in selection of a STEM major in college? A multimethod answer. American Educational Research Journal, 57(1), 218-257. https://doi.org/10.3102/0002831219853533

Steele, C. M., \& Aronson, J. (1995). Stereotype threat and the intellectual test performance of African Americans. Journal of Personality and Social Psychology, 69(5), 797-811. https://doi.org/10.1037/0022-3514.69.5.797 
Stephan, M., Pugalee, D., Cline, J., \& Cline, C. (2017). Lesson imaging in math + science: Anticipating student ideas and questions for deeper STEM learning. ASCD.

Tai, R. H., Liu, C. Q., Maltese, A. V., \& Fan, X. (2006). Planning early careers in science. Science, 312(5777), 1143-1144. https://doi.org/10.1126/science.1128690

Tatum, A. W. (2006, February). Helping struggling students: Engaging African American males in reading. Educational Leadership, 63(5), 44-49. http://www.ascd.org/ASCD/pdf/journals/ed_lead/el200602_tatum.pdf

Tyler, K. M., Thompson, F., Burris, J. L., Lloyd, H., \& Fisher, S. (2016). Internalized stereotypes and academic self-handicapping among Black American male high school students. Negro Educational Review, $67(1-4), 5-31,169$.

Yin, R. K. (2009). Case study research: Design and methods. SAGE Publications.

Young, J., \& Young, J. (2018). The structural relationship between out-of-school time enrichment and Black student participation in advanced science. Journal of the Education of the Gifted, 41(1), 43-59. https://doi.org/10.1177/0162353217745381

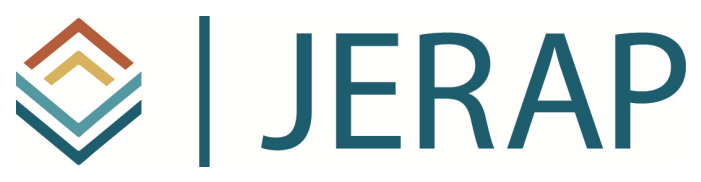

The Journal of Educational Research and Practice is a peerreviewed journal that provides a forum for studies and dialogue about developments and change in the field of education and learning. The journal includes research and related content that examine current relevant educational issues and processes. The aim is to provide readers with knowledge and with strategies to use that knowledge in educational or learning environments. JERAP focuses on education at all levels and in any setting, and includes peer-reviewed research reports, commentaries, book reviews, interviews of prominent individuals, and reports about educational practice. The journal is sponsored by The Richard W. Riley College of Education and Leadership at Walden University, and publication in JERAP is always free to authors and readers. 